TITLE:

\title{
Overview of the clinical application of regenerative medicine products in Japan(Abstract_要旨 )
}

\author{
$\operatorname{AUTHOR}(\mathrm{S}):$ \\ Tsubouchi, Mina
}

\section{CITATION:}

Tsubouchi, Mina. Overview of the clinical application of regenerative medicine products in Japan. 京都大学, 2010, 博士(社会健康医学)

ISSUE DATE:

2010-09-24

URL:

http://hdl.handle.net/2433/126752

RIGHT: 


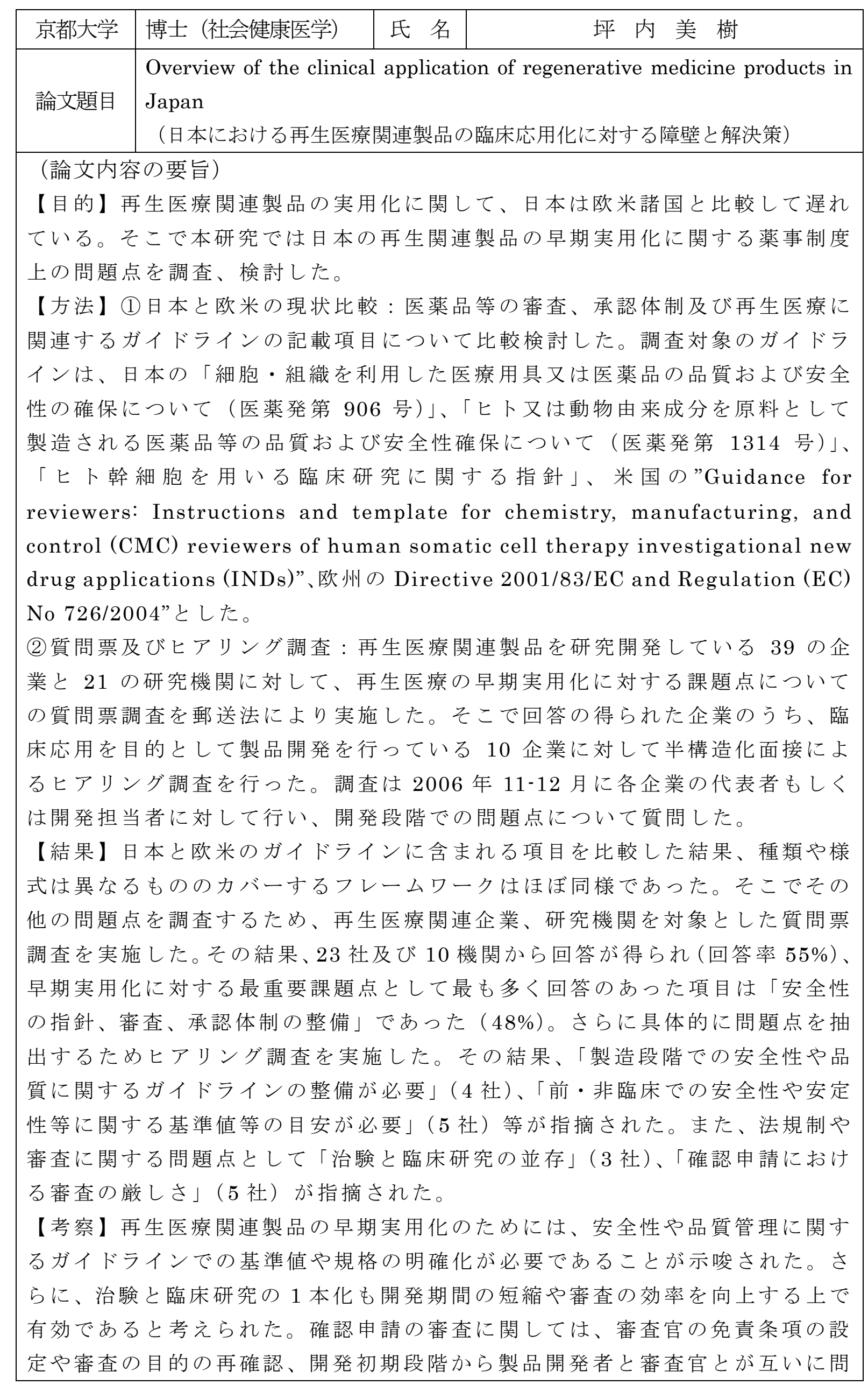

題点を認識していくこと等が円滑に進めていく上で重要であると考えられた。 再生医療関連製品の早期実用化には、今後、これらの課題点を踏まえた社会的 インフラ整備が必要であると考える。なお本研究での提言は、国内における 1314 号通知の改訂や臨床研究倫理指針の改訂に反映されることになり、日本 の再生医療の実用化発展のための基盤構築に大きく貢献できたものと考える。

\section{(論文審查の結果の要旨}

再生医療関連製品の実用化に関して、日本は欧米諸国と比較して遅れている。 そこで本研究では、日本の再生医療関連製品の早期実用化に関する薬事制度上 の問題点を調查・検討した。

まず、日本と欧米の医薬品審査・承認法体系及び体制、また再生医療に関する ガイドラインの記載項目について比較検討した。その結果、種類や様式は異な っていたものの、カバーするフレームワークはほぼ同様であった。

次に、その他の阻害要因を調査するため、質問紙調查及び半構造化面接により、 再生医療関連製品を研究開発する主体を対象とした研究を行った。まず、再生 医療関連製品を研究開発している 39 企業と 21 研究機関に対して質問紙調査を 実施した。その結果、早期実用化に対する最重要課題点として最も回答数の多 かった項目は「安全性の指針、審査・承認体制の整備」であった $(48 \%)$ 。こ でこれらについてより具体的に問題点を抽出するため、質問紙調查で回答の得 られた企業のうち、臨床応用を目的として製品開発を行っている 10 企業に刘 して半構造化面接を実施した。その結果、1314 号通知等の記載内容や安全性 に関するガイドラインの整備、治験と臨床研究の並存、確認申請に倸る審査基 準の厳しさや審查時間の長さに関する問題点が指摘された。以上の結果より、 本研究はこれまで明示されていなかった再生医療関連製品の早期実用化に対 する薬事制度上の問題点の解明に寄与したものと考える。

以上の研究は再生医療関連製品の早期実用化に対する問題点を解明し、日本の 再生医療実用化発展のための基盤構築に寄与したものと考える。したがって、 本論文は博士（社会健康医学）の学位論文として価値あるものと認める。 なお、本学位授与申請者は、平成 22 年 8 月 4 日実施の論文内容とそれに関連 した諮問を受け、合格と認められたものである。 